\title{
The Linguistic Worldview of Contemporary Israeli Writers (E. Kishon, A.B. Yehoshua, A. Oz, M. Shalev, D. Grossman) in Russian Translation:
}

Estrangement and Translation Strategies

\author{
Yulia E. Valkova* \\ Siberian Federal University \\ 79 Svobodny, Krasnoyarsk, 660041, Russia
}

Received 10.01.2017, received in revised form 18.12.2017, accepted 15.01.2018

The article observes the Russian translation of works by contemporary Israeli writers (E. Kishon, A.B. Yehoshua, A. Oz, M. Shalev, D. Grossman) with the emphasis on such literary device as estrangement. Estrangement is seen as the intrinsic part of the linguistic worldview of these authors and as a means of translation, complementary to translation strategies of domestication and foreignization. Estrangement is meant to be specific intonation of the authors of the $4^{\text {th }}$ period of literature in modern Hebrew and is realized in different stylistic and grammar constructions.

Keywords: estrangement, translation, linguistic worldview, E. Kishon, A.B. Yehoshua, A. Oz, M. Shalev, D. Grossman.

DOI: 10.17516/1997-1370-0215.

Research area: philology, translatology, culturology.

\section{Introduction}

Modern Israeli writers are those who were born with rare exception in the 1960-1970s, and it is the fifth wave of Israeli literature. The first wave was the immigrants of the Second Aliyah (Sh.Y. Agnon, D. Shimoni, J. Fikhman, Sh. Tchernichovsky, Y.H. Brenner); the second wave was made of the representatives of Zionism ideology stuck to the state ideology and the kibbutz plain life (U.Z. Grinberg, A. Shlionsky); the third wave was composed by Sabras, these were writers who mother tongue was Hebrew for the first time in modern history ${ }^{1}$ (S. Izhar,
M. Shamir, H. Guri, B. Tammuz, S. Michael, D. Shahar); the fourth wave was comprised by writers, considering Jewish culture against the background of other (not neglecting them), these writers departed from the too realistic chronicles (A.B. Yehoshua, A. Oz, N. Jonathan, I. Ben-Ner, Y. Kaniuk, M. Shalev, D. Grossman, E. Kishon, A. Keinan, A. Apelfeld, D. Ben-Amotz, H. Beer, E. Amir, M. Bezherano). Those are the ones who write in Hebrew, among the writers who wrote in Yiddish prominent ones were S. Ash, D. Pinsky, A. Sutsveker. Among the representatives of the fifth wave we can distinguish A. Dan, E. Keret,

(C) Siberian Federal University. All rights reserved

* Corresponding author E-mail address: julyvalkova@gmail.com 
I. Linur, M. Arad, R. Hen, A. Kimhi, M. Litvack, E. Yakir, but in this article particular attention will be paid to the works of writers of mainly fourth wave, who have already gained the popularity and are icons in the Israel modern literature.

\section{Theoretical framework}

It should be noted that different chronological classifications overlap, so this article is aimed at considering the representatives of the "new wave" or "generation of the state", whose main works were written from 1960 to 2010s, have been translated into Russian and have become relatively popular. Style of the "new wave" features a departure from the ideas of Zionism and the revision of the ideals as regards life "on the ground"2. In her thesis on the structure and genesis of the modern Israeli prose, M.V. Svet remarks that the writers of this period show "a radical change in perceiving reality and their characters: the focus has now been shifted to the individual, inner deep feelings. Prose has become deeply psychological and symbolic. It also affected the form of their works. They were often based on internal monologues of the characters, a description of their dreams, thoughts. The authors started to resort to stream of consciousness, such narrative mode in connection with which the works contained repetitions, certain lexical dissonance and the text roughness, since characters' thought was demonstrated in its development. Along with that, there was the tendency to use materials from different spheres of language, namely borrowings, slang and phraseology, colloquial expressions and new structures" (Svet, 2007: 14). Since all the originality of the works cannot be analyzed within the framework of this article, only one literary device, namely estrangement, will be seen in detail.

The term ostranenie introduced into Russian literature studies by V.B. Shklovsky, or estrangement, is associated with deautomatized perception of things or phenomena that is the most appropriate in describing rethinking of old ideals, the revaluation of Zionism and political beliefs, which engrossed the minds of almost all the writers of this period. Estrangement implies a common generalization, replacement of the word or name expected in this context with another one with the same reference and broader semantic potential. It is presumed that estrangement can be realized at the level of sentence/statements as a metaphorical element (type I) and at the level of context/text, representing a complete stylistic image (type II).

The linguistic worldview of modern Israeli writers and estrangement in their works were scrutinized in Russian translations from Hebrew, as the reproduction of estrangement in the translation may also pose a challenge in a particular case due to the problem of the adequacy of the fiction translation. The linguistic worldview (also rendered as the language picture of the world, hereinafter referred to as LW) is understood as the "mental-lingual formation, elements of which are concepts, i.e., notwithstanding what informems and expressions are actually used in this or that language" (Goncharova, 2012: 398). LW displays information about the surrounding reality, imprinted in the individual or the collective consciousness and represented in the language. Two main functions of LW are interpretive (perception of the world) and regulatory (coordination of speech behavior with what is accepted in the society). In translation the protagonist can even acquire a new identity, as it was proven by Y. Tobin on the material of works connected with Holocaust, whose translations may be easily depersonalized (Tobin, 1993: 316). Estrangement also acts as a translation means, adding some dimension to the text from completely different culture system (Razumovskaya, 2014). In translation into/from Hebrew, estrangement is combined with foreignization due to the fact that 
the Hebrew text is necessarily of "elevated tenor" and "slightly heightened register"3 (Katz-Goehr, 2011: 6).

\section{Discussion}

Let us now proceed to the analysis of LW originality in the most well-known works of separate modern Israeli authors (the selection criterion was existence of Russian translation and a proper readership).

The first of the writers considered anticipates generation of the "new wave": Ephraim Kishon (1924-2005) in 1949 immigrated to Israel from Budapest. By the mid-50s E. Kishon had become the most popular humorist and satirist in the country. His books have enjoyed large circulation (totally 43 million copies were sold all over the world, which is more than the total circulation of all other Israeli writers combined). The seemingly futile stories withstood the test of time and were translated into European and Oriental languages. Using literary Hebrew, E. Kishon, however, writes in a "simple" language, without explicit conversational turns. The distinctive features of his stories, in particular, from the collection of "Thousand of Gadia and Gadia" (1954) are the spectacular combination of words, witty neologisms, wordplay, puns. Borrowings are rare" (Svet, 2007: 12) despite the fact that the writer's native language is Hungarian. Russian translations enlist such books as: "The Family Book" (translated by M. Belen'kii, Gesharim Publishing, 2002), "Scapegoats" (translated by M. Belen'kii, Gesharim Publishing, 2002), "The Fox in the Henhouse" (translated by M. Belen'kii, Publisher Gesharim, 2002), "This is What We Israelis are" (translation by A. Kriukov, Gesharim Publishing, 2004), "Is there an Israeli Sense of Humor?" (translated by G. Raskin) and separate stories, which is not so much compared to 40 separate translations of his works into English, let alone translation of 10 plays.
E. Kishon slants his works in favour of particular topics such as life of small fries, family issues, politics, corruption of officials, fashion. Construction of his satirical sketches is like of those of M. Twain, R. Carver or K. Capek.

Like many other writers, who learned Hebrew at adult stage ${ }^{4}$, E. Kishon demonstrates estrangement, associated with the change of lingua-cultural identity (born Ferenc Hoffmann he changed his name, though his heavy Hungarian accent accompanied him throughout his life): "The stories of Kishon, who himself had to drink the bitter cup of the immigrant, when he got to the East from the European country, reflect many realities familiar to returnees even today; these are hatred of newcomers and strangers, Israelis aggression, the bureaucrats' omnipotence and callousness, the total dominance of the ruling Labour Party" (Belen'kii, 2004). A characteristic sign of E. Kishon's style is a non-trivial look at ordinary things, so a washing machine in "The Washing Machine is Also a Man" (that is a Russian name for the story, literally translated from Hebrew, while English title is "Born to Be Free") acquires the features of a living being. The following description is an example of II type estrangement: "From that time Jonathan wasn't tied with the ropes, as he found this inexplicable, and now we no longer opposed his peculiar way of washing. Jonathan has made us understand that it is born in the land of Israel - a sort of sabra and has an indomitable sense of freedom. We even began to be proud of it. Meanwhile, one day, on the Sabbath, when we, as always, had the guests round for the evening meal, Jonathan allowed himself to break into the dining room and began to pester guests"5 (Kishon, 2008). Translator chose foreignization to translate this passage, what is considered an adequate strategy, though domestication in the English translation while depriving the text of some realia, generalizes the meaning and makes the story as if universal. 
Nevertheless, the Russian translator also used the domestication in this passage, but culture-specific elements are preserved: "sabra" is accompanied with an explanation of the concept (while in the English translation this element is compensated and have an additional component (natural)), borrowing "the Sabbath" alludes to the fact that according to tradition on Saturday one cannot turn on appliances, while washing machine as though by himself, violates the established order. "The Sabbath" remains without explanation, but this is balanced by the context "we had guests round for the evening meal". The machine description given in the masculine gender, this is transfer without adding foreignization, as in Hebrew the "washing machine" is feminine as in Russian.

Estrangement as the exposure of the perception process often happens in the stories of E. Kishon, when he describes the world order, the rules and conventions of society, e.g., Goldfish from Financial Control Department (story "In the Poor Country"), comes to the Minister of Finance and states that he has grown hateful to stealing:

'Mr. Minister, I have a problem, a purely personal one. The fact that I am weary of stealing. At first, I was over the moon with the most opportunities to make money, but now, I'm sorry, I'm sick of it...'

'But why, Goldfish?'

'I do not understand myself. I feel totally devastated. I do know, I have nothing to be ashamed of, as any reasonable person in this country is well aware that having a family with three children it is impossible to live on a salary of one hundred thirty four lire a month. But what depresses me is that I have to steal from the state! Maybe I'm talking nonsense, but there's something humiliating...'

'Goldfish, are you the only one?'
'Of course, I understand. But this still repents me. Here, I wrote, Goldfish pulled out his notebook, according to my calculations, in August I stole ten thousand seven hundred and twelve lire, in September - more than twenty thousand, and in October - six thousand four hundred sixty-five lire, and besides, one firm gave me a bribe of fifteen hundred pounds'.

'Why was such a poor harvest in October?'

'Oh, because I got tired of stealing, Mr. Minister. That's why I came to you. I have a suggestion: can you raise my salary up to two hundred and thirty lire a month, and I'll quit stealing.'

'I'm sorry, my dear Goldfish. There is no money in the budget, and there was no precedent of such fantastic salary increase - almost double! I know your personal problems, Goldfish, but still you have to be content with what you have'. Perhaps, after many-many years, our poor country will become rich enough to be able to afford such luxuries, but not now, not now...'

'Do I have to go on in the same vein?'

'Looks like you have no choice. Take care, Goldfish!'

'Goodbye, Mr. Minister'.

(Kishon, 2004).

Some researchers also trace estrangement to alienation in the Marxian sense. R. Salerno finds estrangement being a sign of modern times, when people feel as if they were denied a place in the world, insecure in a constantly changing world that they do not control. Accordingly, R. Salerno thinks that "to be modern means to feel separation, permanent loss and lack of communication" (as cited in: Dickinson, 2005: 280). It seems typical of many characters of E. Kishon, A. Oz and his predecessor in the "office" - the largest novelist of the time Benjamin Tammuz (1919-1989), whose works shall not be discussed here in detail, as the writer belongs to the previous generation, 
but some of his favoured themes were further developed in the works of later authors. So, the main characters of the B. Tammuz's novels are highly educated people, who speak the "pure" literary Hebrew. Deliberately emphasizing the high level of culture it is no coincidence he chose epistolary genre for some of his books, a certain sublime style (intrinsic of his style). B. Tammuz pays great attention to detail in the descriptions of the characters, however, he does not go into extensive reflections (See in detail: Svet, 2001). Detailing, implying a greater estrangement of the characters (type II estrangement), as well as the sublime style are the characteristic features of the style of the author, which places him in close quarters with A.B. Yehoshua.

Gabriel Abraham Yehoshua (b. 1936) made his debut in 1957 with the stories in the popular newspaper and the journal "Keshet"; since that he has been writing under the pen-name A.B. Yehoshua. In Russian the following works were published: "Summer of 1970" (translated by the Israeli magazine "Time and We", 10, 1976), collection of short stories (translated by N. Sergeeva, ed by Z. Kopelman, Gesharim Publishing/Bridges of Culture, 2001), "Journey to the End of the Millennium" (Gesharim Publishing/Bridges of Culture, 2003), "Five Seasons" (translated by R. Nudelman, A. Furman, Text Publishing, 2007), "Death and Return of Julia Rogaeva" (translated by R. Nudelman, A. Furman, Text Publishing, 2008), "The Return from India" (translated by V. Tublin, Limbus Press, 2010).

A.B. Yehoshua's works are in the genre of magical realism, but the syntax of his work is close to a conversational mode, devoid of deliberate complexity. Estrangement in his works is interconnected with the attempt to re-think the Arab-Israeli conflict, which is imprinted in the spiritual state of the characters. A.B. Yehoshua draws inaccessibility of following moral principles against the backdrop of military conflicts, the gap between older and younger generations of Israelis, the failure of following the religious traditions while creating contemporary Israeli culture.

The author's estrangement results from the desire to stand between the new and the old Yishuv (settlement in Israel), between the Sephardim (to whom he belongs) and the Ashkenazi (constituting the majority of Israeli intellectuals), between sabras and immigrants, between those who have left the fold and yekes (immigrants from Germany). The writer himself admits that he wants to get rid of the unpleasant need to have a "burdensome identity" and would prefer to be called an "Israeli with a Western cultural center of gravity" (as sited in: Golani, 2004: 283). The duality is remarkable in regard to Jerusalem, where the writer consciously decided not to return, considering it a symbol of Zionism, as the inhabitants of Jerusalem perceive themselves as involved in the great history and all their actions are to be considered symbolic (Golani, 2004: 286). In his short story "Three Days and the Child", he describes the feeling of impending catastrophe experienced by staying in Jerusalem even after its reunion (Golani, 2004: 284). In addition, the author expresses the idea that if the temple had been so valuable to the Israelis, after its destruction by the Romans they could have removed its remnants, cleaned the Temple Mount from the debris, which the Arab conquerors made six centuries after that. Such a radical statement along with the other led to the fact that the patriotic Israelis consider A.B. Yehoshua a marginal writer and despise him no matter what he really writes in his fiction (Kariv, Khen, 2011).

Furthermore, A.B. Yehoshua sees no future for the Jewish diaspora outside the borders of Israel, he cherishes nostalgia for the days when people moved to Israel for the sake of life in the 
Promised Land. The writer "creates an ideal concept of a secular Jewish identity, mixed with the deep desire to seek knowledge and ideas" (Lehrer, 2015: 14). He also forces the reader to look at the Jewish archetypes from a different angle and criticizes the traditional beliefs, accusing them of cultivating neuroses. As for the Jews outside Israel, he reproaches this for being a "neurotic response" to the Jewish question (Devir, 2014: 193). Style of his works is similar to F. Kafka's style, but at the same time, A.B. Yehoshua "subverts many well-known Biblical, Talmudic, midrashic and Kabbalistic tropes, unabashedly questioning their moral relevance vis-à-vis those for whom a secular Zionist ethos is paramount" [Ibid]. In his works, the writer creates a world torn from pan-Jewish rhetorics and looks into the internalization of human relations within the Israeli society. A.B. Yehoshua "believes that the absence of a common national framework, in an age of secularism, has created a situation in which world Jewry is held together only by an idea (i.e. 'Jewish'), the definition of which is ambiguous at best" (Devir, 2014: 194). Thus, the writer is focused on the search for a national (but not religious ideal), highlights the need to abandon the policy of militarism and to achieve peace with the neighboring Arab states. N.P. Devir considers A.B. Yehoshua prose to be perceptive, while B. Horn notes that to make events plausible the author gives any hero a genealogy that goes back to the general cultural field of Israelis, thus, for Mr. Mani in the eponymous novel 5-6 previous generations have been described, and his mythological lineage dates back to "the creation of a second generation of the Jewish people in the Binding of Isaac story in Genesis-and the provocative idea that the Jews are attracted to the figure of Isaac" (Horn, 2001: 633).

Estrangement of the writer, as a rule, is I type realized in tropes and denudation of ordinary things: "Water flows grind glass"; "I was exiled by myself and hightail it"; "A huge, so familiar universe, silently drops the tears in front of me" (Yehoshua, 2012). This method concerns ordinary things, those which are here all the time: "And so, page by page there runs daily gibberish, which does go beyond the everyday life by any means, and the character has a special gift to turn even extraordinary events into that nonsense" (Melikhov, 2008).

Nevertheless, there is a general technique that each character is endowed with his/her own voice, there is no narrator in the novel, and it is not clear whose position is shared by the author (estrangement type II). In the early stories the author simply depicts his feelings, and, plunging into his Self, he shows how great the person is while being alone" (Beskrovnaia, 2013: 1314). Critics accuse A.B. Yehoshua of one-sided reporting, neglecting secondary plotlines in favor of introspection: "This unicentric, consistent descriptions invariably suffers from inactivity, lack of events. Moreover, the author is very stingy on the implementation of anything like feelings, attitudes, intentions. All the time we are vexed in the unsteady state of grayscale modality, somewhere between the indicative and subjunctive" (Gart, 2009). This lack of action contributes to the author's estranging intonation.

To create this estrangement the author introduces a meditating narrator (like A. Oz does). Action is interrupted by the glance from outside, for example, when the characters undergo inspection at the airport, this picture is presented through the eyes of the observer not taking part in the process: "A girl is wearing a white, spotless suit whose pocket has a pinned badge with her name. During off-hours she is studying at the Theater Faculty of the college. Now she interrogates them, one by one, in a dry monotonous voice, being interested in the contents of their luggage. But their precise answers do not save them from the requirement to open their 
bags and have their capacious medical backpack checked, too; this examination is accompanied by some surprise about the quality and diversity of medical instruments, it seemed that bad luck with the disease, willy-nilly, are somewhere in there. And the morning frost, which had chased young doctor and his parents throughout their journey from Jerusalem, leaked in a huge departure lounge, bypassing the computer screen checking the boarding passes, while the grayhaired mother and father waved goodbye to their only child, their little one, despite the fact that he was already twenty-nine years old. They put him out to the other parent couple embarking on a journey, who earned confidence due to common in parents' feelings being for them the highest human value" (Yehoshua, 2010).

Translation strategy is foreignization (exoticization) for the estrangement type I, transference (transference) and the reproduction of the author's tone for type II. Yet, foreignization obliges the translator to be careful, because in the Russian translation of "Return from India" there are such shortcomings, literal loans as "starter pedal", "coordinated head", "well-oiled marriage", "bony Jew female", "I do not have a kopeik <...> he gave me two hundred dollars", etc. To translate these and other expressions the translator should have used neutralization or precedent translations. Precedent translations are understood here as "a kind of sustainable equivalence of this unit in another language within this language conceptual sphere" (Minchenkov, 2009: 147).

The next writer considered is Amos $\mathrm{Oz}$ (b. 1939), who made his debut in 1965 with a collection of stories "Where the Jackal Howl", but as early as in 1958 he published his first story in the magazine "Keshet". Since then, many of his works have been translated into Russian with first translations published in Israeli journals in the 1970s. Among the most significant novels there are "Alien Fire" (translated by V. Flanchik, Alia Library, 1989), "In this Unkind Land" (translated by V. Flanchik, Alia Library, 1989), "Ways of the Wind" (translated by V. Radutskii, Raduga, 1993), "My Michael" (translated by V. Radutskii, 2P, 1994), "Black Box" (translated by V. Radutskii, Alia Library, 1996), "A Tale of Love and Darkness" (translated by V. Radutskii, Yediot Akhronot, 2005; Amphora, 2007), "To Know a Woman" (translated by V. Radutskii, Amphora, 2006), "Rhymes of Life and Death" (translated by V. Radutskii, Amphora, 2008), "Rest in Peace Prepared..." (translated by V. Radutskii, Amphora, 2009). The list of English translation is far more extensive (9 non-fiction books, 20 fiction and separate translations of single stories) compared to 9 modern translations into Russian all in all.

The vivid originality of A. Oz's works is that his characters are the representatives of different ethnic groups and followers of various political movements and ideologies that embody the whole spectrum of philosophies and mentality of Israeli society. Estrangement in his works is associated with an attempt to get over the ArabIsraeli and intergenerational conflicts, to see the opportunities for secular life in a religious Israel. Being famous as a peacenik he is as if compelled to assert his right not to portray political matters, but rather "focus on the eternal in life, on love and loss and human bonds, which became, paradoxically, a deeply political act" (Anderson, 2001: 36). The works are full of reflection, characters' introspection, reflection on and comprehension of death. In "Ways of the Wind" estrangement appears in the beginning, when the character perceives routine events in deautomatized mode - "here and now". This keen perception as if anticipates his tragic death: "And the other guy was angry at his back. 'Maybe that's enough, finally? Why are you chatting and blabbing since the early morning?' Gideon 
did not take offense. On the contrary: for some reason these words caused him a surge of joy" (Oz, 1993). Means to achieve the estrangement in this and other works of the author are using historical present tense when describing past events, borrowing of syntactic structures (for the language of the characters, whose native language is not Hebrew); switching modes of narration (from the first to the third person); interchange of characters, when the event is shown through the eyes of different actors; introduction of the observing narrator into the text. A key reason for estrangement is the character's alienation, when he feels lonely and misunderstood, wants to break free from the binding imposed ideals and conventions. The alienation in "A Tale of Love and Darkness" is due to the narrator's attempt to overcome the trauma after the death of his mother. Describing Jerusalem in his works, the writer calls himself "a stranger in a very strange city" (as cited in: Golani, 2004: 287). In addition, the writer explores migrants acquiring different mentality, adaptation to the local customs and desolation due to poor command of a new language and behavior: "The discrepancy between the behavioral and mental codes leads to fatal failures in communication, and this lack of understanding penetrates into the previously reliable family cocoon, corroding it from inside" (Kopelman, 2014: 33).

Contemplation and exploring consciousness are also connected with attempts to understand the nature of memory, to keep bygone events in writing, moreover, A. Oz's LW is closely related to Russian intertext, so introducing the Russian publication of the novel "My Michael" in 1993, A. Oz published an essay "Scorched by Russia", where he writes as follows: "About my relationship with Russia, and, I believe, they are common to most people of my generation, and perhaps for the whole our culture, about these relationships one can say that we are scorched!
And it is impossible to erase the signs, to rub out the traces of this "scorch" associated with the emergence and experience of our tragic and unhappy "Russian affair", we are stamped, stigmatized and singed" (Oz, 1993). Therefore, translation of A. Oz's works should be based on the palimpsest of Russian culture, thus, Russian translation acquires the features of domestication, and the translation into other languages should contain certain foreignization, which is not always the case, e.g. the English translator (or an editor) of "A Tale of Love and Darkness" does not translate text passages related to Russian, while the English translator of "The Russian Novel" of the next writer considered Meir Shalev gives the novel a new name "The Blue Mountain", although this geographical feature is not central to the novel and also obscures the reference to the Russian culture.

Meir Shalev (b. 1948) made his debut in 1969 with the publication of poems in the newspaper "Maariv". Translation into Russian include the major novels and children's books, as well as nonfiction works, popular telling of biblical events. The major novels translated include "Russian Novel” (1988), "Esau” (1991), “As a Few Days...” (1994), "In His House in the Desert..." (1998), "Fontanelle" (2002), "A Pigeon and A Boy" (2006), "It Was Like This" (2009), "Out of the Woods Came Two She-Bears" (2013). The list of publishers and translators (mostly R. Nudelman and A. Furman) is not given here, since there were many republications with all Russian translation made between 2002 and 2015.

M. Shalev's LW, like A. Oz's LW, is closely related to Russian intertext, so the writer was inspired by M.A. Bulgakov's, N.V. Gogol's, V.V. Nabokov's, A.P. Chekhov's Hebrew translations, in his first major work "Russian Novel" characters are Russian Zionists of the "Second Aliyah" (1904-1914), and by the way, "there is something very Russian in Shalev's love 
lines, there is little action and a lot of explicit and implicit reflection, as in Chekhov's "The Lady with The Dog" (Kopelman, 2011: 2). He insists on his stories having universal character: "straddling the twentieth century, his tales are built upon minute observations of the lives of simple folk, of generations of farmers and bakers and the dramas that colour them" (Anderson, 2001: 36).

The writer's estrangement is associated with general "surreal atmosphere of his works, an abundance of quotations and allusions that turn into the intertextual phenomenon" (Maiatskaia 2013: 52). In addition, the writer mixes narrative styles, combines fantastic inventions with realistic descriptions, ridicules biblical scenes, uses a black parody, mocks the value system and total patriotism, brings to conflict between Arabs and Jews to the absurd point: for example, "an ArabBedouin Naif, a cook for the Yofes, perfectly cooked all the dishes of Jewish cuisine, but hardly had she tried something cooked she immediately began to vomit; so she learned that the dish was good. If she did not vomit, she gave food to the dogs, and they, after eating it, could not even get up from the ground" (Maiatskaia 2013: 55). All of these strategies are used to dispell collective myths pathos and the idealization of biblical characters. De-automatization (estrangement type II) is also seen in bringing ideas to the extreme point, as in the novel "In His House in the Desert" all men are killed by accident, and this idea is extrapolated to even grandfather's suicide: "A shiver went through all the spines that crouched outside the gates, that shiver which every irreversible process generates in the bodies of people watching it. Grandfather Rafael, certain that victory over death is already in his hands, tied the rope to a beam barn, stood on a large milk can, stuck his head in the noose and without delay threw the can with his foot. $<$... Everyone looked at Grandmother as she joined other family widows: directly in front of everyone, in this moment and by her own discretion. Grandmother still waited, as if to assure herself that the motionless hanging body finally died, died so securely that no help would revive it. And then, only then, she got up and screamed as if no one was around, as if she had just entered the barn, as if she was shocked to see her husband hanging on the beam. 'Quick, our Rafael hanged himself, quick, bring a knife, oh, I am fainting!" (Shalev, 2010). The author describes the psychological self-estrangement of the households from suicide; also there is a metonymy (estrangement type I): "spines" instead of "people".

De-automatization, like in A. Oz's works, is the choice of a particular language, certain words, being iconic for this character. In "Russian Novel" residents of Kibbutz Nahalal have their speech habits, such as a school teacher talking about children as about the shoots: "They enter the first group as soft as river grass, as the flowers that I should weave into the overall fabric of our lives. Pines never said "a class", he always said "a group". I smiled in the darkness, because I knew what was to happen next. Pines liked to compare education with agriculture. Describing his work, he resorted to such expressions as "virgin land", "curly vine", "drip irrigation". Students for him were "plants", each group - "flower bed" (Shalev, 2006). The translators of this work, as noted by R.R Wisse, "resorted to the language of denials ('did not hear', 'neither ... nor') to liberate the school teacher, to release him from the burden of the national past and allow him to enjoy the direct connection with his land" (Wisse, 2008: 56).

Translation strategies used are foreignization for the author's tone, domestication - for the individual components. The writer himself notes the high quality of his works' translation into Russian (Edelstein, 2012). Translators in turn remark that for the translation of biblical reminiscences it is necessary to carry out detective work, and while M. Shalev's works stand out 
from the crowd because of subtle psychological nature, "exquisitely complex composition, powerful and tragic theme of love-hate, lyricism and irony, unbuttoned fantasy and biblical depth, special puff of phrase" (Edelstein, 2012). The translation challenges are also the characters' deviations from the language norm, which may be applied by the author to "spice up the speech of characters being the representatives of different social strata" (Shpektorova, 2004: 67). These abnormalities are reduced to the incorrect use of prepositions (homonymous to the necessary ones), conjunctions, bad choice of grammatical forms. But the reproduction of such errors in translation will result in common parlance, while the Hebrew mistakes arose from the lack of rules' acquisition (Hebrew is undergoing rapid development and some divergences have not become grave violations so far). It should be pointed out that A.B. Yehoshua's characters speak with abundant deviations from the norm. Apart from mistakes associated with conjunctions, prepositions and incorrect grammatical variants, these are also the article misuse, wrong structures, linguistic incongruity, use of the auxiliary verb together with the notional one, etc. (See in detail: Shpektorov, 2002). In translation, there are no traces of these deviations from the norm, which can be justified by the fact that these violations are frequent in the Israelis' speech and so they are not stylistically marked.

One of the most noted writers and journalists in modern Israel literature is David Grossman (b. 1954), who made his debut in 1979 with the story "Donkeys" and the novel "The Smile of the Goatling" about life in Judea and Samaria under Israeli authority; the latter received the literary prize of the Prime Minister of Israel. The Russian translations include: "Someone to Run With" (translated N. Singer, G. Singer, Fantom Press, 2004), "Lion's Honey: The Story of Samson" (translated by G. Segal, Otkrytyi
Mir, 2006), "See Article: Love" (translated by S. Schoenbrunn, Text, 2007), "Duel: The Story" (translated by R. Nudelman, A. Furman, Knizhniki, 2011), "There are Zigzag Kids" (translated by E. Tinovitskaia, Knizhniki, 2012).

D. Grossman's LW is characterized by the propaganda of Arab interests, paired to condemnation of the state military policy. In his seven novels, the writer describes the generation gap, problems of the young people, who have no special abode; depicts the marginalized people, who turn into decent ones in the end (as in "Someone to Run With"); gives an account of the childhood traumas ("A Horse Once Went in the Bar"), the post-war syndrome and the Holocaust survivors' feelings ("See Article: Love”). Direct speech of characters stands out from the main text stylistically, against the background of literary language: "When I write, I see a lot of behavioral modes in any human situation, and the choice is always in my hands. And I choose the joy of inner freedom, which has been seemingly lost. I enjoy the richness of natural language, its intimacy and depth. When I manage to avoid stereotyping, I begin to breathe deeply and feel that sometimes the accurate use of the word becomes a cure for serious illness, as only correct word brings me back to myself, to me before the conflict and tragedy. I release myself from the role of the enemy, I do not want to feel guilty for my opponent's sufferings of, although I do not shuffle the blame on the enemy completely" (Grossman, 2007).

D. Grossman expresses estrangement in the same way as $\mathrm{A} . \mathrm{Oz}$; the events happening are shown through the eyes of the narrating boy; the work contains multiple voices of different characters with the leitmotiv of loneliness. In "Duel" the boy is lying under the bed and from there is seeing the usual things differently: "I was lying like that, on my stomach, under the bed of Mr. Rosenthal in the House of Pensioners, 
and suddenly it occurred to me that from such a level, from the floor, the world looks pretty scary. From here an ordinary paper basket seemed as big as a barrel, and a little Rosenthal's suitcase towered as a huge gray cabinet. Only Rosenthal's feet, swinging right before my eyes, looked as thin and small as they were really. I thought that, perhaps, infants and children while they are small, always suffer from the fear, because everything seems to them huge and menacing. And it occurred to me that may be the elderly, too, are afraid of the world all the time, because it is too fast and too complex for them" (Grossman, 2011). D. Grossman emphasizes that the task of the writer is "the dismemberment of the soul's protective mechanisms" (Grossman, 2007), which he carries through "self-reflection in the text mirror" [Ibid], so, for example, in the novel "See Article: Love" one and the same event is shown from the four points of view.

While translating D. Grossman's works into Russian, as critics say, it is important not to overfill it with the colloquial and vernacular expressions that would contribute to the "street language" (Prokof'ev, 2005). Thus, the translator of the novel "Someone to Run With" unreasonably uses domestication, while "the author makes everything elegant: he does not make his heroes pronounce clumsy phrases, does not make them speak in criminals' argot, but instead here and there he puts signs of low style. For example, he uses the colloquial 'zoti' rather than intelligent 'zot' ('this' - feminine), $<\ldots>$ while it is bluntly wrong to translate automatically 'zoti" as 'entot' (vernacular phonetic variant for 'this'). In the same way, a professional manager is not to pronounce the word "illiuzioniz'm", even if he heads the drug mafia. A girl who knows the name of Alice's cat from L. Carroll, is unlikely to use such expressions as 'alone in the street this shit won't fly" and "I am a type of thinking about art"
(Prokof'ev, 2005). However, the translations made by other translators maintain a balance between different styles without slipping into the vernacular stylization. Yu. Budman, analyzing the Russian translations, made by N. and G.D. Singer (published in 2004), L. BergerVinokur (which exists only in electronic form), and the English translation made by V. Almong, ascertains that the first translation distorts not only the style, but also the meaning of the text (for example, a girl who became a prostitute, describes her experience as "being out on the street" instead of "walking the track", etc.). The English translation in this respect is more in line with the original text (Budman, 2013: 222 and further). In addition, "N. and G.D. Singer resort to dysphemistic translation to enhance expression. $<\ldots>$ L. Berger-Vinokur, on the other hand, refuses to use coarse language. When translating special features of the characters' speech she chooses neutral language. Thus, her translation does not reflect low style used by the author in the original text, so it seems that the bandit Pesakh speaks normal literary language" (Budman, 2015: 52). Translation by L. BergerVinokur also contains foreignization, which reproduces estranging effect and euphemization.

\section{Conclusion}

This article gave only a brief overview of the linguistic worldview of the modern Israeli authors in Russian translation. Linguistic originality of different writers centers around allusions to Bible literature, reminiscences of world classics, descriptions of the characters' internal conflicts, phantasmagory, even when describing real events (the most vivid in E. Kishon's stories), play of styles, remembrance of works created in other languages and read by the authors. The non-linearity of the narrative and the reference to events far removed in time (as in A.B. Yehoshua novel "Journey to the End of 
the Millennium") allow us to distinguish certain timelessness in the description, and the authors' ability to make personal stories universal (as in A. Oz's "A Tale of Love and Darkness", "Rhymes of Life and Death", M. Shalev's "Russian Novel", "Esau", "It His House in the Desert", "A Pigeon and A Boy"). It should be noted that nearly all significant works of contemporary Israeli writers (with the exception of "Journey to the End of the Millennium") are related to the characters' reflection on their own place in Israel, with insight into the themes of national identity, traditional religion and Zionist ideals?

The reasons for estrangement in the works of Israeli writers are the following: 1) a desire to evaluate the Arab-Israeli conflict objectively; 2) an attempt to overcome the bond with the older generation of writers and related ideals Zionism, life on the ground, exaltation of physical labor ${ }^{8}$; 3) the changing worldview of the narrator. In addition, the Israeli writers start to realize that they can have "no desire to be the Jewish mouthpiece <..> In Israel, there are writers who turned their Jewishness into an important source of creativity, but for most others this is an obsession, a nightmare that they are striving to shake off quickly" (Wisse, 2008: 56).

Authors choose estrangement: 1) to demonstrate the events through the prism of other people perception; 2) to cast light on duality of the existing binary oppositions, functioning as mental constructs (contradictions between Jews and Arabs, religious and secular, old and new immigrants, children and adults, etc.); 3) to reproduce the event as a novelty and deautomatize habitual actions. For rendering estrangement writers uses graphics (italics, quotation marks, borrowings, which can be easily recognized in the text because of the different alphabet), lexical means (the use of certain words, borrowings and expressions from different registers), syntactical means (a combination of direct, indirect and reported speech in long passages, usually without helpful punctuation; the use of the present historical time) and stylistic means (internal monologues, which reveal the characters' detachment, self-reflection, switching narrative modes from "I" to "you"; the use of different genres, documents, lists to give a narration documentary character, displacement of temporary layers).

Translation strategies for estrangement are foreignization and the exact reproduction of syntactic constructions. In the case of allusions to the works of Russian literature (in A. Oz's and M.Shalev's works) the translators apply domestication and compensatory means to recreate the sense of alienness. The future work in this streak may involve detailed studying of translation techniques used in the translation of literature from Hebrew to Russian and other languages.

\footnotetext{
Coupled with the revival of Hebrew, which started its way from the Classical Biblical one and was embarking on a long journey, now being far more complex than it had ever been before: "the reemergence of Hebrew as a vernacular resulted in the rise of a prestigious native usage, which initially demarcated Israeli from Diaspora existence" (Reshef, 2011: 158).

2 This linguistic and cultural kibbutz identity can even be realized through grammatical categories, namely the system of future tenses (See in detail: Tobin, 1990: 500).

3 Hebrew as a language has long been connected with the concept of power and magic involved in acting by speaking only (cf. Thon, 2012: 105).

4 Sh. Avni argues that acquisition of Hebrew did not itself construct a Jewish reality, though it evokes Jewishness: "While Hebrew does not clearly fit into one of the three types of heritage languages that delineates in that it is neither an immigrant, indigenous, or colonial language, nor are its students raised in a home where Hebrew is spoken as the language of communication, its learners have a cultural, religious, and historical connection to the language" (See in detail: Avni, 2012: 324).

5 Compare with the English translation of the passage: "We realised it would not be wise to tie up Jonathan again since he obviously resented it. After this incident we left him to his laundering in complete freedom. Somehow we got used to the idea that our washing machine was a noble Israeli animal which would not tolerate any kind of rein. Only once, on a Saturday night, it caused an unpleasant incident when it burst into the dining room and started annoying our guests" (See
} 
in detail: https://books.google.ru/books?id=ytvrnmtIxggC\&pg=PA80\&lpg=PA80\&dq=The+Washing + Machine + is + also $+\mathrm{a}+$ man+kishon\&source=bl\&ots=No60QG4dM_\&sig=S96FIRFp3hccIurjJTsVvoCj8-Y\&hl=ru\&sa=X\&ved=0ahUKEw ihp534wcjQAhVID5oKHeiTDJkQ6AEIGzAA\#v=onepage\&q=The $\% 20$ Washing $\% 20$ Machine $\% 20$ is $\% 20$ also $\% 20 \mathrm{a} \% 20$ man\%20kishon\&f=false)

6 Both in Russian and Hebrew the word "roman" means "novel" and "long love affair".

7 H. Rimon meanwhile states that "Israeli post-Zionist literary criticism, which randomly applies to Israeli literature those models that were developed in Anglo-American postcolonial theory, manifests a typical blindness as it overlooks meaningful patterns which do not conform to the existing postcolonial stereotypes" (Rimon, 2011: 244). In this regard the researchers neglect, as she points out, the tendency of Israeli writers to bring lucrimax into sharp focus. The latter term was introduced by Russian philosopher A.M. Etkind as an anagram for simulacrum. The new term is an affirmation of the Other authenticity and a denial of the Self authenticity. Lucrimax is created by situations of dual faith, deviousness and biculturalism, whatever their origin. Lucrimax is logically and historically associated with chiliasm. Those who have declared contemporary culture simulative, believe in the end of history and post-history, the new version of the last days. When people name anything that they do not love about their culture a simulacrum, this is also lucrimax (see in detail: https://religion.wikireading.ru/81490).

8 The national and cultural identity is not a solid matter, now "old identities of the tough and rough Sabra mix in with a more hedgy style of interaction" (Ariel, 2011: 1155). It entails new recognition of Hebrew identity and constant revision of the personal identity.

\section{References}

Anderson, H. (2001). POLITICS OR LITERATURE? In Jewish Quarterly, 48 (4), 35-38. doi: 10.1080/0449010X.2001.10706726

Ariel, M. (2001). Book Review on Maschler, Y. and Benjamins, In J. Metalanguage in Interaction: Hebrew Discourse Markers, Amsterdam, 2009, 258 p., In Journal of Pragmatics, 43, 1154-1156.

Avni, Sh. (2012). Hebrew as heritage: The work of language in religious and communal continuity, In Linguistics and Education, 23, 323-333.

Belen'kii, M. (2004). Efraim Kishon: ot myt'ia tualetov k mirovoi slave [Ephraim Kishon: from cleaning toilets to world fame], In Migdal Times, available at: http://www.migdal.org.ua/israel/3729/

Beskrovnaia, E.N. (2013). Otrazhenie temy lichnosti cherez problemu "malen'kogo cheloveka" v tvorchestve A.B. Iehoshua [Reflecting the personality theme through the problem of the "little man" in the works of A.B. Yehoshua], In Literatura v konteksti kul'turi [Literature in Culture Context], 23(2), 9-15.

Budman, Yu. (2013). Roman Davida Grossmana "Mishehu larutz ito" i ego perevod na russkii iazyk [David Grossman's novel "Mishehu larutz ito" and its Russian translation], In Tirosh - Trudy po iudaike [Tirosh: Proseedings on Jewish Studies],13, 219-228. Moscow, 234 p.

Budman, Yu. (2015). Osobennosti peredachi rechevykh kharakteristik personazhei D. Grossmana " " v vשימ צורל ותא" D. Grossman's novel “"והשימ צורל ותא"], In Evreiskaia rech' [The Jewish Speech], 4. Saint-Petersburg, 40-56.

Bugeja, N. (2015). Reincorporative trajectories: The threshold as emblem in Amos Oz's A Tale of Love and Darkness and Orhan Pamuk's Istanbul: Memories of a City, In Journal of Postcolonial Writing, 51:1, 7-21, DOI: 10.1080/17449855.2014.983696

Devir, N.P. (2014). Exposing pathology, playing God: parsing psychosocial discourse in 'The Last Commander' by A.B. Yehoshua, In Jewish Culture and History, 15, 3, 188-211.

Dickinson, J. (2005). Review on Landscapes of Abandonment: Capitalism, Modernity, and Estrangement, by Roger A. Salerno. Albany: State University of New York Press, 2003. 270 p. In Contemporary Sociology: A Journal of Reviews, 34, 3, 279-281.

Edelstein, M.A. (2012). "My prochli i poniali, chto eto nash avtor" (beseda s perevodchikami M. Shaleva - R. Nudelman and A. Furman) ["We have read this and understood that this is our author" 
(conversation with M. Shalev's translators - R. Nudelman and A. Furman)], In Lekhaim, 2 (238), available at : http://www.lechaim.ru/ARHIV/238/interview.htm

Gart, D. (2009). Zapad est' zapad, vostok est' vostok [West is West, East is East], In Lekhaim, 1 (201), available at: http://www.lechaim.ru/ARHIV/201/gart.htm

Golani, M. (2004). "If I lived there it would crush me" Jerusalem from the Biographical to the Historical and Back: A Conversation with A. B. Yehoshua, In Journal of Israeli History, 23, 2, 279-300.

Goncharova, N.N. (2012). Iazykovaia kartina mira [The Linguistic Worldview], In Izvestiia Tul'skogo gosudarstvennogo universiteta. Gumanitarnye nauki [Bulletin of the Tula State University. Humanities], 2, 396-405.

Grossman, D. (2007). Pisatel'stvo v zone tragedii [Writing in the tragedy zone], available at: http://booknik.ru/library/all/pisatelstvo-v-zone-tragedii/

Grossman, D. (2011). Duel. Moscow, Text, Knizhniki, available at: http://www.litmir.me/ $\mathrm{bd} / ? \mathrm{~b}=166037$

Horn, B. (2001). The Plot of Suicide in A. B. Yehoshua and Leo Tolstoy, In The European Legacy, 6, 5, 633-638.

Kariv, A., Khen, R. (2011). Mechtaia o romane [Dreaming about the novel], In Lekhaim, 10 (234). available at: http://www.lechaim.ru/ARHIV/234/aktualii.htm

Katz-Goehr, A. (2011). A Dream of Translating the Dream into Hebrew, In Journal of SinoWestern Communications, 3, 2. Israel, The Hebrew University of Israel, 3-22.

Kishon, E. (2004). Eto my-izrail'tiane [This is What We Israelis are], available at: http://heblit. org/0txt/ekiwi.html\#z_toc_005

Kishon, E. (2008). Rasskazy iz tsikla "Smert' na provode" [Stories from the series "Death on the Wire”], available at: http://www.lib.ru/PXESY/KISHON_E/prowod.txt

Kopelman, Z. (2011). O russkom podtekste sovremennoi ivritskoi literatury [On Russian subtext of modern Hebrew literature], In Vestnik Evreiskogo Universiteta [Herald of Hebrew University], 14, available at: rjews.net/zoya-kopelman/articles/Russian-Presence-Vest-1.doc

Lehrer, N. (2015). Baggage Carousel Conversations with George Steiner and A.B. Yehoshua, on Jews, Jewishness and Israel, In Jewish Quarterly, 62, 11-14.

Maiatskaia, E.L. (2013). Mifologicheskie motivy kak sredstvo postmodernistskoi ironii v romane Meira Shaleva "Fontanella" [Mythological motives as a means of post-modern irony in Meir Shalev's novel "Fontanelle"], In Vestnik Sankt-Peterburgskogo universiteta [Bulletin of St. Petersburg State University], 13, 4, 52-60.

Melikhov, A. (2008). Retsenziia na knigu A.B. Iehoshua "Piat' vremen goda" [Book Review on A.B. Yehoshua's "Five Seasons"], In Znamia [Colours], 6, available at: http://magazines.russ.ru/ znamia/2008/6/me23.html

Minchenkov, A.G. (2009). "Pretsedentnye perevody" kak perevodcheskaia problema ["Precedent translations" as a translation problem], In Vestnik Sankt-Peterburgskogo universiteta [Bulletin of St. Petersburg State University], 9, 4 (2), 146-149.

Oz, A. (1993). Puti vetra [Ways of the Wind]. Moscow, Raduga, available at: http://heblit.org/text. php?ge $=$ prose $\& \mathrm{ac}=\mathrm{ao} \& \mathrm{tc}=\mathrm{aoww}$

Oz, A. (1994). "Opalennye Rossiei" (esse) ["Scorched by Russia" (the essay)], available at: http:// heblit.bravepages.com/ao/aobr.html 
Prokof'ev, D. (2005). Biznes na "luzerakh". Retsenziia na knigu D. Grossmana "S kem by pobegat"” [Business on “losers". Book Review on D. Grossman's “Someone to Run With"], In Lekhaim, 4 (156), available at: http://www.lechaim.ru/ARHIV/156/n3.htm

Razumovskaya, V.A. (2014). Kul'turnaia informatsiia: adaptatsiia i ostranenie v perevode [Cultural information: Adaptation and estrangement in translation], In Professional'no-orientirovannoe obuchenie inostrannym iazykam. Materialy VIII nauchno-prakticheskoi konferentsii [Professionallyoriented foreign language teaching. Proceedingss of the VIII scientific and practical conference]. Ekaterinburg,Ural State Pedagogical University,125-129.

Reshef, Y. (2011). Book Review on Nevo, N. and Olshtain, E., (Eds.). 2007. The Hebrew Language in the Era of Globalization. Magnes Press, Jerusalem, In Language \& Communication, 31, 158-159.

Rimon, H. (2011). In the Desert of the Other: Identity and Lucrimax in Modern Hebrew Fiction, In Australian Journal for Jewish Studies, 25, 222-245.

Shakhovskii, V.I. (2015). Meniaiushchaiasia kartina mira v dinamike iazyka i rechi [The changing linguistic worldview in the language and speech dynamics], In Vestnik Volgogr. Gos. Univ. Ser. 2. Iazykoznanie [Herald of Volgograd State University. Series 2. Linguistics], 1 (25), 7-20.

Shalev, M. (2006). Russkii roman [Russian Novel]. Moscow, Text, 638 p., available at: http:// royallib.com/book/shalev_meir/russkiy_roman.html

Shalev, M. (2010). V dome svoem v pustyne [In His House in the Desert]. Moscow, Text, Knizhniki,672 p., available at: http://loveread.ec/contents.php?id=35359

Shpektorova, N.I. (2002). Iazykovaia norma v sovremennoi izrail'skoi khudozhestvennoi literature (na primere romana A.B. Iehoshua "The Lover") [The language norm in contemporary Israeli literature (on the basis of A.B. Yehoshua's novel "The Lover")], In Iazyk ivrit: issledovanie $i$ prepodavanie. Materialy Deviatoi ezhegodnoi mezhdunarodnoi mezhdistsiplinarnoi konferentsii po iudaike [The Hebrew language: research and teaching. Proceedings of Ninth annual international interdisciplinary conference on Jewish studies]. Moscow, Sefer,183-195.

Shpektorova, N.I. (2004). Iazykovaia norma v sovremennoi izrail'skoi khudozhestvennoi literature (na primere romana M. Shaleva "Esav") [The language norm in contemporary Israeli literature (on the basis of M. Shalev's novel "Esau")], In Iazyk ivrit: issledovanie i prepodavanie. Materialy Desiatoi i Odinnadtsatoi ezhegodnykh mezhdunarodnykh mezhdistsiplinarnykh konferentsii po iudaike [The Hebrew language: research and teaching. Proceedings of Tenth and Eleventh annual international interdisciplinary conferences on Jewish studies]. Moscow, Sefer, 62-67.

Svet, M.V. (2007). Ivrit sovremennoi izrail'skoi [prozy: genesis i stroi [Hebrew of modern Israeli prose: genesis and structure], Abstract of Thesis of Candidate of Philological Sciences. Moscow, MSU, 26 p.

Thon, J. (2012). The Power of (Hebrew) Language: Grammar, Cabbalah, Magic and the Emerging Protestant Identity, In European Journal of Jewish Studies, 6, 1, 105-122.

Tobin, Y. (1990). The Future Tense in Modern Hebrew: From Sign to Text, In Folia Linguistica, 47, 457-512.

Tobin, Y. (1993). To Remember and Forget: Masken in Frankfurt. The Semiotics of Prejudice in Translating an Israeli Holocaust Novel Into German, In Folia Linguistica, 27 (3-4), 315-346.

Wisse, R. (2008). Sovremennyi evreiskii literaturnyi kanon. Puteshestvie po iazykam i stranam [Contemporary Jewish literary canon. Travel across languages and countries]. Moscow, Jerusalem, Bridges of Culture / Gesharim, 512 p. 
Yehoshua, A.B. (2010). Vozvrashchenie iz Indii [Return from India]. Moscow, Limbus-Press, 648 p, available at: http://loveread.ec/view_global.php?id=37635

Yehoshua, A.B. (2012). Neskonchaemoe bezmolvie poeta [Never-ending silence of the poet], available at: http://www.rulit.me/books/neskonchaemoe-bezmolvie-poeta-read-165514-10.html

\title{
Языковая картина мира современных \\ израильских писателей (Э. Кишон, А.Б. Иегошуа, \\ А. Оз, М. Шалев, Д. Гроссман): \\ остранение В. Шкловского и стратегии перевода
}

Ю.Е. Валькова

Сибирский федеральный университет

Россия, 660041, Красноярск, пр. Свободныій, 79

\begin{abstract}
Статья посвящена описанию языковой картины мира у современных израильских писателей 4-ой волны (на материале русских переводов избранных произведений Э. Кишона, А.Б. Иегошуа, А. Оза, М. Шалева, Д. Гроссмана). Проанализировано употребление такого приема, как остранение, выполняющего роль связующего средства для произведения авторов этого периода. Остранение рассмотрено как стилистический и переводческий прием, дополняющий переводческие стратегии доместикаџии и форенизаџии.

Ключевые слова: остранение, перевод, языковая картина мира, Э. Кишон, А.Б. Иегошуа, А. Оз, М. Шалев, Д. Гроссман.

Научная специальность: 10.00.00 - филологические науки, переводоведение, 24.00.00 - культурология.
\end{abstract}

